\title{
SŁOWO WSTĘPNE
}

Dążenie do poznania prawdy i przekazywanie wiedzy z pokolenia na pokolenie stanowią szczególnie szlachetną działalność człowieka, która urzeczywistnia się głównie w powołanych przez społeczeństwo do wypełniania tej misji uniwersytetach. Nierozerwalny związek badań naukowych z kształceniem studentów, doktorantów, kadr uczelni, a także słuchaczy studiów podyplomowych, we wzajemnej korelacji z krajowym i międzynarodowym otoczeniem społeczno-gospodarczym, jest od lat konkretyzowany we właściwym mu zakresie na Wydziale Prawa, Administracji i Ekonomii Uniwersytetu Wrocławskiego. Przez te wzajemnie przenikające się i zespolone w nierozerwalną całość formy życia akademickiego ziszcza się idea służby człowiekowi, społeczeństwu, demokratycznemu państwu prawnemu — rozwojowi cywilizacji.

Przedkładany teraz sto dwudziesty tom „Przeglądu Prawa i Administracji” obejmuje wyniki badań naukowych prowadzonych na naszym fakultecie, który wkomponowuje się w ten organiczny nurt aktywności Uniwersytetu Wrocławskiego. Uzyskana przez Wydział w ostatniej ewaluacji jakości działalności naukowej najwyższa nota, kategoria $\mathrm{A}+$, jest rezultatem wysiłku całej naszej wspólnoty. To szczególne wyróżnienie w świecie nauki nastąpiło w czasie nabycia przez Alma Mater statusu uczelni badawczej w programie Inicjatywa Doskonałości - Uczelnia Badawcza. Wszystko to sprzyja między innymi dalszemu umocnieniu i internacjonalizacji najwyższej próby badań naukowych, rozwojowi wysokiej jakości kształcenia, także na kierunkach anglojęzycznych, oraz kolejnym działaniom na rzecz sfer życia publicznego i prywatnego we współczesnym świecie. Absolwenci są naszymi ambasadorami.

W roku jubileuszowym 2020 wydane zostały także dwa uznane (uaktualnione) opracowania: Pamięci zmartych Profesorów i Docentów Wydziału Prawa, Administracji i Ekonomii Uniwersytetu Wrocławskiego 1945-2020. Księga wydana z okazji jubileuszu siedemdziesięciopięciolecia Wydziału Prawa, Administracji i Ekonomii Uniwersytetu Wrocławskiego (pod redakcją Lucyny Lehmann i Marka Maciejewskiego, Wrocław 2020) oraz Wydział Prawa, Administracji i Ekonomii Uniwersytetu Wroctawskiego w fotografiach (1945-2020). Księga wydana z okazji jubileuszu siedemdziesięciopięciolecia Wydziału Prawa, Administracji i Ekonomii Uniwersytetu Wrocławskiego (opracowała Lucyna Lehmann, Wrocław 2020). 
Podjęte w tym roku trzy inicjatywy wydawnicze oraz inne działania mają na celu podziękowanie, oddanie czci oraz okazanie ogromnego szacunku dla tych, którzy budowali pozycję i prestiż naszego fakultetu. Pragniemy, aby dawni i współcześni zasłużeni na zawsze pozostali w naszej pamięci. Wiadomo przecież, że Uniwersytet to sztafeta pokoleń.

Dziekan, prof. dr hab. Karol Kiczka 